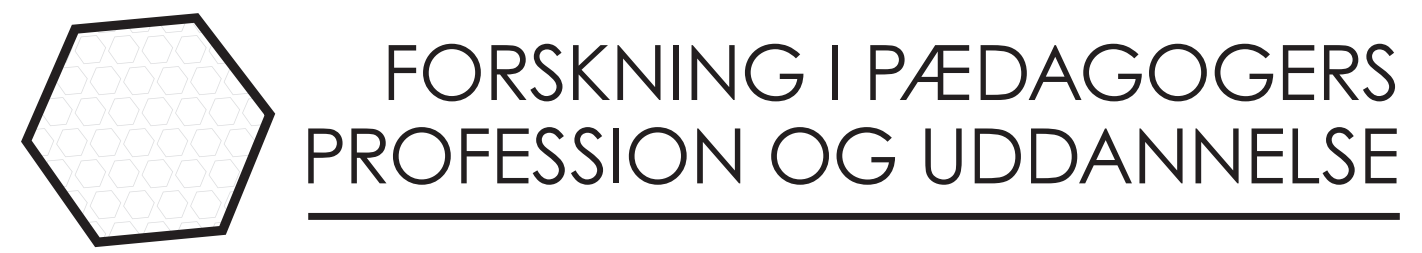

\title{
Diskussionen om opdragelse
}

- om ansvar, autoritet og balancer

\section{Eva Gulløv}

Lektor og phd, Danmarks Institut for Pædagogik og Uddannelse evag@edu.au.dk 


\title{
Resumé
}

Artiklen diskuterer den aktuelle debat om opdragelse og viser, hvordan den må forstås i lyset af nogle historiske ændringer i synet på børn og opvækst. Med inspiration fra figurationssociologien vises det, hvordan der har været en udvikling fra et mere hierarkisk syn på relationen mellem børn og voksne til en jævnbyrdig og uformel generationel omgangsform med en mere barnesensitiv opdragelsesform. Denne opdragelsesform er imidlertid under skarp kritik, fordi den ikke passer særlig godt med vilkårene i daginstitutioner og skoler. Artiklens viser, hvordan det er denne diskrepans mellem idealer for børn og praktiske vilkår i institutionerne, der har givet anledning til usikkerhed og den aktuelle debat om, hvad der er de rigtige opdragelsesværdier, og hvilken rolle og ansvar forældre har.

\begin{abstract}
The discussion of upbringing - responsibility, authority and balances

This article focuses on the current debate on upbringing in Denmark and argues that it should be seen in light of historical changes in the view of children and upbringing. There has been a shift from a more hierarchical perception of the relationship between children and adults, to a more informal approach stressing generational equality and the need for a child-sensitive form of care and upbringing. However, this approach is currently criticised as it does not match well with the frames and conditions of contemporary day-care institutions and schools. This discrepancy between ideals for children and practical conditions in the institutional settings has given rise to uncertainty and debate about the right form of upbringing and the role and responsibility of parents.
\end{abstract}

\section{Nøgleord}

Opdragelse, forældreskab, figurationssociologi, barnesyn, børneinstitutioner, generation

\section{Keywords}

Upbringing, parenthood, figurational sociology, perception of children, child-institutions, generation 


\section{Indledning}

Debatten om børneopdragelse er tilbagevendende og har været det længe. Bare inden for de sidste 30 år er debatten blusset op ca. hvert andet år og har kaldt på heftige meningsudvekslinger i diverse medier. I 1990'erne blev udtryk som 'curlingbørn' og 'den nye børnekarakter' introduceret i en stærkt bekymret tone over, hvad den aktuelle opdragelse (eller mangel på samme) ville få af konsekvenser for den opvoksende generations psyke og selvstændighed (se f.eks. Hougaard 2000; Egelund 2004). Her en generation senere er det fortsat den samme type emner, der drøftes. Således kan man f.eks. se, hvordan det i 2014 diskuteres, om børn er blevet 'konger' og 'kontorchefer' i deres hjem (Korsaa \& Hougaard 2014); om servicerende forældre underminerer deres børns livsduelighed og robusthed (f.eks. Skovbo 2015, 2016); eller om børn generelt mangler respekt for lærere og pædagoger (se f.eks. Søgaaard \& Jørgensen 2017). Aktuelt har vi så 'opdragelsesdebatten' som børne- og socialminister Mai Mercado satte i gang 30. januar 2018. I oplægget efterspørger ministeren viden og bud på, hvad opdragelse er, men begrunder også initiativet med en bekymring over den måde børn er opdraget på, som hun ser som årsag til uro i skoler og lærere og pædagogers udfordringer med børn (http://socialministeriet.dk/opdragelsesdebat). Den genkomne diskussion om børns opdragelse bliver hver gang livlig. Der udveksles stærke holdninger om børn og opdragelse, om statens rolle i forhold til familiens autonomi, om forældres opgaver og ansvar og deres samspil med professionelle. Et gennemgående tema over de sidste 30 år er, om næste generation vokser op som selvcentrererede egoister uden sans for fællesskabet og uden respekt for voksne. Altid udtrykt med en tone af bekymring for børnene såvel som for fremtidens samfund.

Det er som sagt langt fra nyt, at der er en offentlig diskussion om børns opdragelse, eller statslige tiltag ift. forældre (jf. Donzelot 1979; Kristensen \& Schmidt 1986; Rose 1989; Block \& Popkewitz 2001; Knudsen 2010). Men det er nyt, at debatten er så omfattende, og at der tages så mange initiativer til at guide forældre i opdragelse og understøtte deres engagement i børnenes daginstitutioner og skoler (Dannesboe et al. 2018). Nogle tiltag relaterer til den elektroniske udvikling, hvor forældre forventes at følge med i og understøtte deres børn gennem daglige opdateringer på intranet eller sms'er og billedoverførsler til smartphones; andre tiltag har form af rådgivningstilbud til forældre eller deciderede opdragelsesprogrammer og kurser rettet mod at forebygge hjemlige problemer såvel som utilpassede børn i institutionerne. Selvom mange elementer i opdragelsesdebatten går igen over årene, er der altså nu en intensiveret opmærksomhed på forældrerollen, på opdragelse og på samarbejdet mellem professionelle og forældre. Det er denne opmærksomhed, som artiklen her er optaget af at undersøge: Hvad er den udtryk for, og hvad fortæller den os om aktuelle opfattelser af forholdet mellem børn og voksne? Med inspiration fra figurationssociologien, der beskæftiger sig med, hvordan opfattelser ændrer sig over tid i takt med forskydninger i sociale relationer, vil jeg argumentere for, at opdragelsesdebatten afspejler ændringer 
i opfattelser af børn. Fra et mere hierarkisk syn på relationen mellem børn og voksne, har der udviklet sig en jævnbyrdig og uformel generationel omgangsform og en mere barnesensitiv opdragelsesform, der ikke altid harmonerer særlig godt med de institutionelle vilkår i daginstitutioner og skoler. Som jeg vil diskutere til sidst i artiklen, er det muligvis denne diskrepans, der bag den aktuelle kritik af forældres måde at opdrage på. Artiklen må ses som en kommentar til debatten; et forsøg på at belyse hvorfor der er så stor opmærksomhed på børn og deres opdragelse, og hvorfor det vækker så stor bekymring.

\section{Fokus på forceldreansvar}

Som påpeget i flere nyere studier, er den intensiverede opmærksomhed på opdragelse og forældres rolle ikke kun et dansk fænomen (Sparrman, Westerling, Lind \& Dannesboe 2017; Dannesboe, Back, Kjær \& Palludan 2018). Flere af forskerne påpeger, at der generelt i Vesteuropa er opstået en parenting culture, et begreb der dækker over en udbredt forståelse af, at forældreopgaven fordrer særlige færdigheder og opmærksomhed, men også et særligt ansvar (Lee et al. 2014). Bevidstheden om barndommens betydning for det enkelte menneskes psykologiske udvikling har øget opmærksomheden på, hvor vigtigt det er, at forældre drager den rette omsorg og stimulerer barnet ikke bare for det enkelte barns skyld, men også for samfundets sammenhæng. Sociologen Frank Furedi (2002, s. 58-60) peger med begrebet infantil determinisme på, hvordan der med den psykologiske viden er etableret en udbredt forstålse af, hvad barndommen betyder for et menneskes udvikling, og dermed hvor vigtigt det bliver, at forældre sikrer deres børn en god opvækst. Med begrebet forceldredeterminisme indkredser han desuden den opmærksomhed, der gradvist er flyttet fra børn til forældre, og viser, hvordan dårlig forældreindsats i stigende grad bruges som forklaring på afvigelse, sociale problemer og manglende uddannelse (ibid.). Der har i skandinavisk sammenhæng været en lang tradition for, at børn under skolealder tilbringer hverdagene i daginstitutioner, og der er derfor et tæt samarbejde mellem pædagoger og forældre om opdragelsen af de yngste. Alligevel er der også her en stærk forventning til forældre om at tage ansvar for børnenes opdragelse. Det er omfanget og grænserne for dette ansvar, som den genkomne debat kredser om. Tager forældre deres ansvar alvorligt nok? Er de for optaget af at understøtte deres egne børns trivsel og personlige udvikling, så de ikke lærer dem at tage hensyn og vise respekt for andre og f.eks. gøre som der bliver sagt i daginstitutioner og skoler.

Trods den stærke debat om, hvorvidt forældre evner deres opgave, er der en del, der tyder på, at forældre generelt tager på sig, at de har ansvaret for deres børns opdragelse og netop derfor søger vejledning og samarbejde med professionelle pædagoger og lærere. Det ser man af den store tilslutning, der er til forældrekurser i de kommuner, der har oprettet sådanne tilbud; det ser man af efterspørgslen på forældre- og opdragelseshåndbøger, og det fremkommer i flere undersøgelser, hvordan forældre på mange måder viser engagement og støtter op om deres børns 
liv i institutioner og rådspørger de professionelle (se f.eks. Knudsen 2010; Dannesboe, Kryger, Paludan \& Ravn 2012; Wissö 2012; Bach 2015; Axelvoll 2016; Dannesboe et al. 2018). I en aktuel undersøgelse af forældresamarbejde mellem pædagoger og forældre fremgår det således, hvordan forældre aktivt søger pædagogernes rådgivning og ser dem som sparringspartnere i opdragelsesspørgsmål (Dannesboe et al. 2018.). Der er således ikke noget, der tyder på, at forældre generelt forsøger at unddrage sig deres ansvar

\title{
Foraldre og padagogers syn på opgaven
}

Også i flere af mine egne empiriske undersøgelser udtrykker de interviewede forældre generelt en optagethed af opdragelse og bevidsthed om deres eget ansvar. Det blev især tydeligt i mit seneste forskningsprojekt, der baseret på et ca. 4 måneder langt feltarbejde, undersøgte forældres og pædagogers syn på børns opvækst i en mindre by i Sønderjylland 2016-17 (Gulløv \& Gulløv, forventet udgivelse primo 2019). De interviewede forældre understreger i samtalerne, at opdragelse er et emne, de er optaget af og finder vigtigt. Kristina, der er mor til to, siger f.eks. meget klart, at både hun og hendes mand 'lægger vægt på, at de [børnene] kan opføre sig ordentligt'. 'Nu er de jo små, men de skal kunne blive siddende ved bordet til alle er færdige, sige 'tak for mad', give hånd til voksne og hilse, mens de kigger i øjnene'. ... 'Det er jo os, der skal opdrage dem, og det synes jeg er rigtig vigtigt'. Også Sara, der er enlig mor til tre understreger, at hun går meget op i deres opdragelse. 'De skal kunne opføre sig ordentligt, når de er på udebane'. Da jeg spørger hende om, hvad hun lægger vægt på, svarer hun:

\begin{abstract}
Sara: Men jeg går meget ind for den der gammeldags opdragelse. Selvfølgelig skal de også have frihed, men til en vis groense. Jeg bryder mig ikke om børn, der ikke har respekt. Det er stadigvoek vigtigt, det der med at vise respekt for celdre mennesker og ... Altså når nu Kamille har voeret ovre hos August, og de har fået en is. Så spørger jeg: 'huskede du så at sige tak?' Altså det synes jeg er en helt almindelig ting, at man gør, når man får nogle ting. Og hun skal også laere at give hånd, når der kommer nogle. Dér må man ikke vare genert.

Eva: Oplever du, at de voerdier du har om, hvordan børn skal opføre sig, når de er på udebane, svarer til institutionens opdragelsesidealer?

Sara: Ja det tror jeg egentlig. De laegger også meget vcegt på opdragelse.
\end{abstract}

Som det fremgår af de små uddrag her, lægger disse forældre vægt på, at deres børn kender til gode manerer og kan opføre sig på en måde, forældrene kan være bekendt. Antropologen Dil Bach viser noget lignende i sit studie af forældre i et helt andet social segment fra Nordsjælland (Bach 2015). Der er ikke ud fra disse studier noget, der tyder på, at forældre ikke går op i deres børns opdragelse. Og der er heller ikke noget, der tyder på, at de ikke er indstillet på at samarbejde med pædagoger og lærere om det eller betragter hjem og institution som to helt adskilte sfærer. Tværtimod tyder både mine egne interviews og andres undersøgelser altså på, at forældre ser opdragelse som et centralt anliggende for dem, 
at de tager ansvaret på sig, og at de lægger meget vægt på samarbejdet med pædagogerne, som de opfatter som eksperter i børneopdragelse.

Samarbejdet er også et genkomment tema i interviewene med det pædagogiske personale i samme undersøgelse fra Sønderjylland. De siger samstemmende, at de lægger meget vægt på at opbygge et godt samarbejde med forældre, men flere forklarer også, at de oplever forældre i dag som mere usikre på, om de er gode nok til at opdrage og derfor mere $\mathrm{i}$ behov for at spørge pædagogerne til råds. Pædagogen Stine forklarer mig f.eks., at hun oplever, at forældre kommer og spørger meget. 'Altså de virker mere usikre. De kan komme og spørge, hvad barnet skal have på, eller hvad vi synes, de skal have med på madpakke'. 'Det er jo ikke, fordi det gør noget. Det giver tit en god snak, men nogle gange undrer jeg mig lidt. Det er som om, de er bange for ikke at være gode nok og ikke rigtig ja sådan tør stole på deres egen fornuft. Altså det er jo ikke dem allesammen'. Også hendes leder forklarer, at hun oplever, at især mange af de unge forældre kommer og spørger til råds. 'De virker ret usikre på, om de gør det rigtige. Men også nogle af de modne forældre er bange for, at de ikke gør det godt nok. Så vi har en opgave dér, som jeg ikke synes, vi havde tidligere. Måske er der bare kommet mere fokus på forældrerollen og på børn'. Pædagogmedhjælperen Trille synes mere, at det handler om, at børnene har ændret sig: 'Jeg oplever egentlig, at børn i dag er mere egocentrerede, end de var for 10 år siden. Det er meget 'mig', 'mig', 'mig'. Jeg tror, det handler om, at forældre inddrager børn i så meget altså alle mulige beslutninger og ikke siger nok fra over for dem. Børn er ikke vant til at indpasse sig og vente på andre'. Da jeg spørger hende, om hun oplever, at forældrene ikke tager sig nok tid til deres børn, skynder hun sig at sige: 'nej tværtimod. Det er jo nogle projekter for dem. Det er nok det, der er problemet. De er så bange for at gøre noget galt, så børnene får alt for meget at skulle have sagt. De er slet ikke vant til at blive sagt imod'. Som det fremgår, er det pædagogiske personale på én gang indstillet på et tæt samarbejde med forældrene, men oplever også nogle udfordringer. Forældrene forekommer mere opsøgende og usikre, og selvom det ikke er gennemgående i materialet, at det faglige personale ser børn som problematiske på den måde, som Trille gør i det sidste citat, er det heller ikke nogen enestående ytring. Lignende vurderinger fremsættes også i andre af mine interviews ikke bare i denne sidste undersøgelse, men helt tilbage til slutningen af 1990'erne. Det er således ikke nogen ny karakteristik, at forældre på én gang er for usikre og for ihærdige, og at det i sig selv giver problemer i skoler og daginstitutioner.

Det, der står frem af materialet her såvel som andres undersøgelser er således, at til trods for den genkomne kritik er opdragelse et emne, som forældre går op i, ligesom de er optaget af deres egen rolle, ansvar og samarbejdet med pædagoger og lærere. Men hvorfor er der så denne store opmærksomhed og debat om opdragelse? Her vil jeg pege på tre forhold, som jeg derefter vil diskutere mere udførligt: For det første at børns symbolske status og kulturelle betydning har ændret sig markant over de sidste 70 år. Der er i dag en større opmærksomhed på børn, deres velbefindende og udvikling end nogensinde før, og den indbefatter en 
opmærksomhed på forældrenes indsats og den antiautoritære pædagogik, der har vundet hævd i perioden. I forlængelse heraf vil jeg for det andet argumentere for, at forældre snarere end at være uengagerede i opdragelsen af deres børn er usikre på, hvilken slags opdragelse der skal være, og fordi børn er kommet så meget i centrum, en bekymring for ikke at gøre nok og det rigtige. Når denne usikkerhed og bekymring synes stærkere i dag, skyldes det imidlertid ikke bare den forøgede opmærksomhed - forældredeterminismen, men også at gældende normer udfordres, og at der er mange mere eller mindre implicitte forventninger at leve op til og balancere imellem. Der er med andre ord strid om opdragelsens karakter. For det tredje vil jeg pege på, at selve det forhold, at børn tilbringer så store dele af deres hverdag i samfundets institutioner, har gjort det vanskeligere for forældre at håndtere opdragelsesopgaven og dermed leve op til det ansvar, de også selv føler, at de har. Samtidig er det nogle meget forskellige arenaer børn befinder sig i og dermed helt forskellige forventninger, der er til deres opførsel hjemme og i daginstitutioner/ skole. Den opdragelse, der finder sted i hjemmene, er derfor ikke nødvendigvis særlig velegnet til institutionerne, og her står forældrene med den udfordring, at de bliver ansvarliggjort for, hvordan børnene opfører sig i sammenhænge de pr. definition ikke har indflydelse på og kun begrænset adgang til. Her rejser der sig nogle dilemmaer omkring karakteren af opdragelse, der ikke kun handler om ansvarsfordeling, men også om de sammenhænge, som børn skal begå sig i i dag.

\section{Barnets symbolske status}

Som påvist af mange forskellige forskere, er der sket store ændringer i opfattelser af børn. Med en historisk analyse argumenterer sociologen Vivianna Zeliser allerede i 1994 for, hvordan børn i Vesten har ændret værdi fra at være økonomisk ressource til at være emotionel uvurderlig, og antropologen David Lancy viser med en gennemgang af tværkulturelle studier af børn, hvordan der i de fleste vestlige samfund er sket en regulær ikonisering af det barnlige, hvor forældre forventes at yde det yderste for deres børn (2008, s. 76). Antropolog Marianne Gullestad (1997) viser en bevægelse fra at se børn som et vilkår i tilværelsen til at indgå i den norske nationalsymbolik. Det investeres store summer og mange kræfter i varetagelse af deres behov og trivsel også for at sikre nationens omdømme. Disse og andre studier viser, hvordan der gennem de sidste hundrede år i mange samfund er kommet ikke bare en stigende opmærksomhed på børn og deres behov, men også en symbolsk ikonisering af barnet som udtryk for det anstændige samfund. De er flyttet fra primært at være et familieanliggende til at være et stadig mere prioriteret kulturelt, politisk og økonomisk område og omsorgen for dem i både hjem og børneinstitutioner er blevet et centralt samfundsanliggende. Den vellykkede varetagelse af børns udvikling og opdragelse bevidner såvel forældres dygtighed som samfundets demokratiske sindelag og sociale anstændighed (Kjørholt \& Lidén 2004; Gilliam \& Gulløv 2012, s. 57-58). Børn i dag er, med 
antropologen Nicole Hennums ord, 'foreldrenes fremste symbol på vellykkethet eller mislykkethet' (2015, s. 4), og kunne man tilføje også på det velfungerende og civiliserede samfund. Og fra det perspektiv er også opdragelsen af dem rykket fra periferien af den kollektive opmærksomhed mod centrum. Diskussionen af opdragelse handler i bund og grund om de mennesker og det samfund, man gerne vil have. Men det er også derfor debatten bliver så ophedet. Det handler om langt mere end konkrete børn, nemlig synet på samfund og samvær (Gilliam \& Gulløv 2012, s. 58). Børn er blevet et samfundsprojekt og netop derfor er der tilbagevendende en debat om dem og deres udvikling og om fordelingen af ansvar mellem hjem og stat.

Kigger man mere overordnet på debatten kan man se nogle ganske store ændringer i synet på børn og opdragelsen over de sidste 70 år. Som uddybet andet sted ændrede synet på børn, opdragelse og forældreskab sig gradvist gennem 60'erne, 70'erne og 80'erne fra en mere myndig opdragelsesstil til en mere uformel og anti-autoritær omgang mellem forældre og børn (Gilliam \& Gulløv 2012; 2017). I årtierne efter 2 . verdenskrig kom netop opdragelse i fokus i den kollektive refleksion over, hvad der havde ført til opbakningen til de totalitære styreformer (nazismen og fascismen og sidenhen de autoritære systemer i Østeuropa). Kritikken blev rettet mod disciplinære former og en lydighedstænkning, som blev set som underminerende for individets frie udvikling af kritisk bevidsthed. Børn skulle have mulighed for at udvikle sig gennem aktiviteter, de selv fik indflydelse på; de skulle føle motivation for deres gøremål og ikke mindst lære at udtrykke sig reflekteret og kreativt. Man skulle skabe et mere humant samfund gennem opdragelsen af selvstændigt tænkende og demokratiske samfundsborgere (se f.eks. Nordentoft 1944, Sigsgaard 1947, Rifbjerg 1969, Øland 2010). I det projekt stod samfundets opdragelsesinstitutioner - børnehaver og skoler - centralt. Det var her, man kunne ændre ved samfundets indgroede autoritære strukturer ved at forme den opvoksende generation. Selvom sådanne tanker vandt noget gehør allerede i 50'erne, varede det længe inden de nød generel udbredelse i praksis. Det er nok først ind i 1980'erne, at man kan tale om, at det store flertal af børn bliver inddraget i beslutninger, der angår deres eget hverdagsliv, eller bliver spurgt i forbindelse med arbejdsemner og aktiviteter i daginstitutioner og skoler. Og det er nok også først på det tidspunkt, at hierarkiet mellem børn og voksne er så ændret, at børn kan tale, før de blive spurgt; ikke behøver frygte autoritetspersoner eller korporlig afstraffelse, og ikke behøver markere distance f.eks. gennem tiltaleformer som 'De', 'fru' og 'frøken' til voksne uden for hjemmet.

Disse skift i synet på børn og voksne, opdragelse og forældreskab afspejler dog ikke bare ændrede holdninger forårsaget af den offentlige debat eller af ændrede politiske forhold som f.eks. ratificeringen af FN's børnekonvention. Som påpeget af sociologen Norbert Elias hænger ændringer i omgangsformer og -normer uløseligt sammen med bevægelser i de sociale strukturer, eller det han kalder figurationer (Elias 1970). Det var også tilfældet i årtierne efter krigen. Med velfærdsstatens etablering, ændringer i produktionsforhold og det økonomiske opsving i 60erne 
skete væsentlige forskydninger i de sociale magtstrukturer og i folks relationer til hinanden. Arbejderklassen rykkede ind i middelklassen, kvinderne kom ud på arbejdsmarkedet - ikke mindst ind i velfærdsinstitutionerne, - og den nye ungdomsgeneration blev en gruppe med egne penge og en bredere adgang til uddannelse (Gilliam og Gulløv 2017). Der skete kort sagt en udjævning af sociale hierarkier i forhold til klasse, køn og generation og dermed et opgør med etablerede klasse specifikke dyder og manerer, generationshierarkier og patriarkalske former. Sociologen Cas Wouters (2004) beskriver det som en informaliseringsproces; en proces hvor de hidtidige formelle koder, der udtrykte distance og stand, blev nedtonet til fordel for en mere uformel og egalitær omgangsform mellem folk af forskellig social stand, mellem lærere og elever, voksne og børn, mænd og kvinder. Markering af hierarki og standsforskelle blev i tiltagende grad genstand for tabuisering - også i generationshierarkiet (Elias 1998; Wouters 2007).

I et essay om ændringer i forældres rolle og opgaver beskriver Elias, hvordan der er sket en generel demokratisering og emotionalisering af relationerne mellem voksne og børn, hvor håndhævelse af autoritet især med fysisk magt gradvist er blevet forbundet med skam og statustab (Elias 1998). I takt med at børns symbolske status er øget, er familien blevet en mere demokratisk institution, hvor de enkelte medlemmers følelser og erfaringer er kommet langt mere i centrum (ibid.). Det har skabt andre forventninger til forældrerollen. Fra en rolle som autoritativ og instruerende opdrager skal forældre i dag lytte, inddrage og understøtte det enkelte barns udvikling og følelsesliv (Gulløv 2016). Engagementet er således ikke blevet mindre; tværtimod er der i dag udtalte forventninger til omfanget og måden forældre skal støtte deres børn på. Men denne opgave er ikke enkel. Uden klare hierarkier eller noget entydigt kodeks for opførsel er meget mere overladt til den enkeltes situationsfornemmelse og sociale jugement. Og det er den fornemmelse, som forældre forventes at kunne give deres børn, også i forhold til situationer, hvor de ikke selv er tilstede.

\section{Den balancerede opdragelse}

Ser man på nutidens børneopdragelse i familien såvel som i daginstitutioner og skoler er det tydeligt, at de egalitære idealer og de uformelle relationer og omgangsformer er blevet udbredte. Hvor man tilbage i 1960'erne priste det artige barn, der slog øjnene ned ved irettesættelser og svarede voksne med respekt, værdsætter man nu i højere grad det selvstændige barn, der kan indgå i dialog med både andre børn og voksne, ser andre mennesker i øjnene, kan tage stilling og argumentere for sine synspunkter. Det udfarende og voldsomme barn vækker fortsat bekymring, men det gør det stille barn også. Børn må hverken være udadreagerende eller introverte, for tilpassede eller for selvoptagne (Gulløv 2016). Der lægges vægt på samarbejde og konfliktløsning, såvel som at børn føler motivation og engagement og selvstændigt kan løse opgaver. Forældre skal understøtte udviklingen af det situationsbevidste og afbalancerede barn, der hverken er kuet 
eller for frembusende, for afhængig af andres retningsanvisning eller for egenrådig. Barnet skal kunne optræde som en selvstændig person samtidig med, at det skal tilpasse sig en gruppe, der synkront deltager i de samme aktiviteter. Idealet om demokratisk inddragelse, barnets deltagelse og selvstændige udvikling er kort sagt blev alment anerkendt og udbredt, men rummer også en række modsatrettede krav til børn og forældre - ikke mindst når det gælder hverdagen i børnehaver og skoler.

I stedet for normative anvisninger af, hvad der er rigtig og forkert optræden, retter det opdragende arbejde sig således mod at vejlede børn i at tage bestik af situationer, andres perspektiver og implicitte fordringer. Denne form for vejledning forudsætter indlevelse og samtale, dvs. den er baseret på fælles fortolkninger af oplevelser, erfaringer og følelser. Det er selvfølgelig langt fra alle forældre, der gør det i praksis, men ikke desto mindre udtrykkes der i både rådgivning og i den offentlige debat om opdragelse en forventning om, at forældre investerer tid og energi i deres børns følelsesliv og engagerer sig i at guide dem i, hvordan de kan fortolke og vurdere både deres egne og andres udtryk (jf. Bach 2015). Også i pædagogiske institutioner lægges der vægt på en sådan anti-autoritær interaktion og guidning med prioritering af verbalisering af indtryk, overvejelser og begrundelser. Ja faktisk i en grad, så følelsesudtryk og sociale kompetencer indgår i en række pædagogiske programmer såvel som i målsætninger i de fleste daginstitutioner og skoler.

Den balancerede optræden (for uddybning se Gilliam \& Gulløv 2012; 2013) er et ideal, men også en udfordring for opdrageren. Forældre, men også pædagoger og lærere står overfor den udfordring at skulle lære børn at afstemme deres opførsel til skiftende situationer og tilpasse sig vekslende krav, og samtidig må de ikke være så føjelige, at de ikke står ved sig selv. Som en af pædagogerne i undersøgelsen oven for udtrykker det: 'Jeg synes jo, det er enormt vigtigt, at de lærer at kunne omgås andre, ja altså sådan have respekt for andres følelser og samtidig kan indgå i et fællesskab. ... Men samtidig skal de også lære, at de selv er gode nok - så det er jo en eller anden balance, for de skal heller ikke blive sådan helt tilpassede'. Den udfordrende balancegang gælder således også de voksne opdragere. De skal både kunne rumme det enkelte barn i al dets særlighed og udstikke rammer for et fællesskab, uden at de kan henvise til et etableret normkodeks. De skal vide, hvornår de skal beherske sig, og hvornår der skal udvises autoritet ('udstikkes grænser') uden at blive autoritær (Gilliam \& Gulløv 2013). Disse udfordrende balancer er så meget desto vigtigere, fordi de er en uomgængelig del af de sociale relationer i dag. Det gør en forskel ift. status og social anerkendelse, om man evner at indgå smidigt i vekslende situationer, kan beherske sig, og at man kan udtrykke sig på en måde, der anerkender og tilgodeser de tilstedeværende uden at markere overlegenhed eller dominans. Og det gør en forskel for ens anseelse, om man som opdrager magter den udfordrende opgave at indvie sine børn i disse subtile balancer, så de opfører sig med tilstrækkelig situationsbevidsthed, uanset hvilken social sammenhæng de selvstændigt færdes i. 
Som jeg ser det, er det ikke mindst den øgede opmærksomhed på børn i kombination med disse krævende balancer, der er årsagen til den genkomne opmærksomhed på opdragelse. I forskellige afskygninger går kritikken på, at børn ikke får tilstrækkelig klare retningslinjer, og det efterlader dem uden pejlemærker og ansvar for fællesskabet (se f.eks. Jensen 2006; Foros \& Vetlesen 2014). Det påpeges, at forældre skal tage mere ansvar og lederskab ikke bare for egen skyld, men også for børnenes og i sidste ende for samfundets (Jørgensen 2017). Der argumenteres med andre ord for et klarere og mere tydeligt kommunikeret normgrundlag, der ikke lægger op til situationsbestemte afvejninger og forhandlinger. Forsvarere af den anti-autoritære pædagogik peger på, at netop evnen til selvstændigt at fortolke, at kunne gå i dialog, tage beslutninger og indgå smidigt i vekslende sociale sammenhænge er selve fundamentet for et funktionelt demokrati og en kulturel kerneværdi i de skandinaviske samfund (se f.eks. Alexander \& Sandahl 2014; Biesta 2015).

\section{De institutionelle fordringer}

Et særligt tilbagevendende tema blandt kritikere har som sagt været, at børn er for urolige i skolen og ikke i tilstrækkelig grad hører efter henstillinger fra pædagoger og lærere. Det er også afsættet for ministerens initiativ til den aktuelle debat. Børns måde at omgås hinanden og voksne harmonerer tilsyneladende ikke særlig godt med hverdagen i daginstitutioner og skoler med mange børn og få voksne. Der rejses derfor kritik - ikke ved skolernes eller daginstitutioners normeringer, struktur eller organisation, men af børnene og dermed af forældrenes opdragelse af dem. Det er en kritik af vægten på forhandling og demokratisk inddragelse og de uformelle og uhierarkiske relationer, som stiller autoritetspersoner som lærere og pædagoger i en vanskelig position. De skal på én gang holde styr på et stort antal børn og sørge for, at alle kommer igennem det samme faglige stof og samtidig tage sig af det enkelte barn og understøtte dets personlige udvikling. Det vanskeliggøres, når børnene forventer at blive behandlet individuelt, ligeværdigt og demokratisk. Frimodighed, diskussionslyst og autoritetsanfægtelse opleves som et regulært problem i institutioner, der er tilrettelagt for at behandle børn som en gruppe, der alle skal passe ind i den samme struktur. Og det problem øges, når børn tilbringer længere tid i daginstitution og skoler med flere børn, dårligere normeringer og fastlagte faglige programmer.

Selvom der i debatten er en generel tone af, at dagens børneopdragelse er for normløs, er det ikke nogen helt rimelig kritik. Dels viser de indledningsvis omtalte undersøgelser som sagt, at i hvert fald nogle forældre lægger meget vægt på at vejlede deres børn om, hvordan de skal opføre sig både hjemme og ude; dels stilles der faktisk ganske mange krav til børn ikke mindst i de institutioner, de tilbringer en stor del af deres hverdag i. Når man sidder og observerer i børnehaver og skoler, kan man således iagttage, hvordan der på én og samme tid er en tilsyneladende uformel omgangsform og rigtig mange implicitte forventninger til, 
hvordan man skal opføre sig (Gilliam \& Gulløv 2013). Der er ganske vist ingen formaliserede tiltaleformer, regler for omgang eller tydelige autoritetsmarkører. Men der er mange mere implicitte normer f.eks. for hvor højt, hvor og hvornår man må tale; hvordan man skal respondere, når andre siger noget; hvor meget man må fylde i lyd og bevægelser; hvordan man forhandler, placerer og bevæger sig; hvordan man fanger pædagogens eller lærerens opmærksomhed eller inkluderer nogle og holder andre ude af en leg eller et samarbejde. Der er en anti-autoritær etos, der understreger demokratisk inddragelse, den enkeltes unikhed og ret til at udtrykke sig og jævnbyrdige relationer børn imellem og mellem generationer. Men der er samtidig temmelig faste tidsstrukturer, programmer, rammer, hierarkier og kutymer, der reelt ikke giver megen mulighed for forhandling eller hensyn til individuelle lyster og synspunkter. Disse sammensatte, men subtile forventninger betyder, at der i realiteten stilles ret store krav til hvert enkelt barns dømmekraft og tilpasningsevne. Hvis man vil undgå at blive irettesat eller betragtet som urolig eller dårligt opdraget, skal man kunne afkode situationen og de tilstedeværende forventninger og afstemme sin optræden og udtryksform derefter. Det betyder samtidig, at de professionelle skal agere i en dilemmafuld pædagogik, hvor de skal lære børn rummelighed og hensyntagen i strukturer, der ikke levner meget rum for fleksibilitet og individualitet.

\section{Afrunding}

Som jeg ser det, er det denne dilemmafyldte pædagogiske praksis, der kan forklare den genkomne debat af forældres svigtende opdragelse og børns egoisme. For de anti-autoritære, barnesensitive og demokratiske opdragelsesidealer harmonerer ikke særlig godt med den institutionsform, der i børnehaver og skoler i samme periode har udviklet sig med mange børn, lange dage, relativt færre voksne og øgede krav og forventninger til karakteren af børnenes læringsmæssige udbytte. I takt med at der er kommet mere samfundsmæssig opmærksomhed på børn og deres symbolske status er øget, er forventninger til børneinstitutionernes indhold og udkomme blevet større og deres form og karakter mere standardiseret. Det tidligere ideal om, at daginstitutioner skulle have en hjemmelignende karakter med mest mulig tid til børns egne afprøvninger, er blevet erstattet af et ønske om at forberede børn bedst muligt til skolens normer og krav. Men dermed er forskellen på hjem og børneinstitutioner også blevet mere markant. Der er en grundlæggende forskel på at være mange børn samlet om en bestemt indiskutabel læringsmæssig dagsorden og være få børn i en familie med interesse i omsorg, samvær og gensidig udveksling. Og der er en diskrepans mellem idealer for den enkeltes udvikling, som i høj grad vægtes i hjemmene, og det hensyn til institutionsfunktionalitet, der i praksis må prioriteres i dagens børneinstitutioner. Konstateringen af denne diskrepans rejser så spørgsmålene: Er det børnene, der er noget i vejen med? Er det forældrenes opdragelse? Eller er det vores institutionsorganisering, der ikke matcher de idealer samfundet samtidig hylder? 
Her vil jeg mene, at debatten om opdragelse fortjener den nuancering, det er at se på de fordringer, der er i de forskellige institutionstyper, som børn tilbringer deres hverdag i, og diskutere om de stemmer overens, men også om de skal stemme overens, og hvad det stiller af udfordringer for de forskellige opdragere. Det er jo ikke nødvendigvis de anti-autoritære idealer, der er noget i vejen med eller den barnesensitive pædagogik, der lægger vægt på at forstå børns erfaringer og følelser og hjælpe dem gennem samtale og vejledning. Der er heller ikke nødvendigvis noget $i$ vejen med at søge at inddrage børn $i$ beslutninger og forpligte sig på begrundelser og argumentation. Men det fungerer ikke altid særlig smidigt i forhold til de betingelser, der er for pædagogisk udøvelse i vores institutioner i dag. Det er således en overvejelse værd, om vi kan blive bedre til at diskutere udfordringer med urolige børn i børnehaver og skoler, ikke som en brist ved hverken børn, forældre eller professionelle, men som et udslag af sammensatte og til tider modsatrettede værdier og forventninger. Og om vi kan blive bedre til at erkende de grundlæggende forskelle, der er mellem familien som institution og de offentlige børneinstitutioner. Måske er det vores børneinstitutioner, der trænger til andre organiseringsformer og betingelser for at opdrage, snarere end at vi ændrer ved idealerne om inddragelse, deltagelse og respekt for den enkelte? Et godt samarbejde om opdragelse forudsætter, at der bliver mere opmærksomhed på sådanne forhold dvs. institutionernes forskellige karakter og muligheder og på sammenhængen mellem værdier og betingelser. Ikke desto mindre vil opdragelse nok altid være et konfliktfyldt område, fordi det afspejler forskellige opfattelser og værdier i forhold til både børn og samfund og familiens og statens ansvar og råderum.

\section{Litteratur}

Alexander, J. \& Sandahl, I. (2014). The Danish Way of Parenting. København: Ehrhorn Hummerston.

Akselvoll, M. (2016). Folkeskole, forceldre, forskelle. Skole-hjem-samarbejde og forceldreinvolvering $i$ et forceldreperspektiv. Ph.d. afhandling, Roskilde Universitet.

Bach, D. (2015). Overskudsfamilier. Om opdragelse, identitet og klasse blandt velstående familier $i$ Nordsjoelland. Aarhus: Aarhus Universitets Forlag.

Biesta, G. (2015). Democracy in the kindergarten. Helping young children to be at home in the world. In: K.E. Jansen, J. Kaurel \& T. Pålerud, Demokratiske praksiser i barnehagen. Bergen: Fagbokforlaget.

Bloch, M. \& Popkewitz, T.S. (2001). Administrating freedom: A history of the present. Rescuing the parent to rescue the child for society'. In: K. Hultqvist \& G. Dahlberg (eds.), Governing the Child in the New Millenium. New York: Routledge Falmer.

Dannesboe, K.I. (2012). Passende engagement og (u)bekvemme skoleliv. Et studie af børns navigationer mellem skole og familie. Aarhus Universitet, ph.d. afhandling.

Dannesboe, K.I., Kryger, N., Palludan, C. \& Ravn, B. (2012). Hvem sagde samarbejde? Et hverdagslivsstudie af skole-hjem-relationer. Århus: Aarhus Universitetsforlag

Dannesboe, K.I., Bach, D., Kjær, B. \& Palludan, C. (2018). Parents of the welfare State: Pedagogues as Parenting Guides. Social Policy \& Society, online 31. January. 
Donzelot, J. (1979). The Policing of Families. New York: Pantheon Books.

Egelund, N. (2004). https://www.kristeligt-dagblad.dk/kronik/m-vi-bede-om-opdragelse-tak

Elias, N. (1939 opr. 1994). The Civilizing Process. Oxford: Blackwell.

Elias, N. (1970). What is Sociology?New York: Columbia University Press

Elias, N. (1998). The civilizing of parents. In: J. Goudsblom \& S. Mennell (eds.), The Norbert Elias Reader. Oxford: Blackwell.

Foros, P.B. \& Vetlesen, A.J. (2014). Angsten for opdragelse. Dannelse I et samfundsetisk perspektiv. Viborg: Forlaget Klim.

Furedi, F. (2004). Therapy Culture. London: Routledge.

Gilliam, L. \& Gulløv, E. (2012). Civiliserende institutioner. Om idealer og distinktioner i opdragelse. Aarhus: Aarhus Universitetsforlag.

Gilliam, L. \& Gulløv, E. (2013). At balancere på slap line. En analyse af aktuel pædagogik. Tidsskriftet Vera nr. 63.

Gilliam, L. \& Gulløv, E. (2014). Making Children 'Social'. Civilising institutions in the Danish welfare state. Human Figurations, vol. 3, issue 1.

Gilliam, L. \& Gulløv E. (2017). Civilisering og distinktioner. Med Norbert Elias i skole og daginstitution. Tidsskrift for professionsstudier, nr. 24.

Gullestad, M. (1997). A Passion for Boundaries: Reflections on Connections Between the Everyday Lives of Children and Discourses on the Nation in Contemporary Norway. In: Childhood. Vol.4 (1).

Gulløv, E. (2016). Følelseshåndtering i et socialhistorisk perspektiv. Dansk Sociologi, nr. 3/4.

Gulløv, E. \& J. (forventet udgivelse 2019). Lokale hensyn, nationale orienteringer. Perspektiver på børn og unges opdragelse og uddannelse i provinsen. Århus: Aarhus Universitetsforlag.

Hennum, N. (2015). Makten i barnet. Tidsskriftet Norges barnevern, 02, vol. 92.

Hougaard, B. (2000). Curlingforceldre og service-børn. Debat om vort nye børnesyn. Vejle: Hougaards Forlag

Jensen, H. (2006). Det faderløse samfund. København: People's Press.

Jørgensen, P. S. (2017). Robuste børn. Giv dit barn ansvar, livsmod og tiltro til sig selv. København: Kristeligt Dagblad

Kjørholt, A.-T. \& Lidén, H. (2004). Children and Youth as Citizens: Symbolic Participation or Political Actors? In: H. Brembeck, B. Johansson \& J. Kampmann (eds.), Beyond the Competent Child. Exploring Contemporary Childhoods in the Nordic Welfare Societies. Roskilde: Roskilde University Press.

Knudsen, H. (2010). Har vi en aftale? Magt og ansvar i mødet mellem folkeskole og familie. Frederiksberg: Nyt fra Samfundsvidenskaberne (Narayana Press)

Korsaa. F. \& Hougaard, B. (9. februar 2014). Danske børn er små konger og kontorchefer. Berlingske.

Lancy, D. (2008). The Anthropology of Childhood. Cambridge: Cambridge University Press.

Lee, E., Bristow J., Faircloth, C. \& Macvarish, J. (eds.) (2014). Parenting Culture Studies. Basingstoke and New York: Palgrave Macmillan.

Nordentoft, I. M. (1944). Opdragelse til demokrati. København: Eget forlag.

Rifbjerg, S. (1969). Børnepsykologi og opdragelse. København: Folkeuniversitetsudvalget.

Rose, N. (1989/1999). Governing the Soul. The Shaping of the Private Self. London: Routledge.

Schmidt, L.-H. \& Kristensen, J.E. (1986). Lys, luft og renlighed: Den moderne socialhygiejnes fødsel. København: Akademisk Forlag.

Sigsgaard, J. (1947). Samfunds-Børnehaven. In: Norsk Poedagogisk Årbog 1946-47.

Skovbo,T. (3. april 2015). Lær børnene modgang. Berlingske, kronik.

Skovbo, T. (24. februar 2016). Lad dit barn stå på egne ben. Berlingske, kronik.

Sparrman, A., Westerling, A., Lind, J. \& Dannesboe, K.I. (eds.) (2016). Doing good Parenthood. Ideals and Practices of Parental Involvement. Basingstoke and New York: Palgrave Macmillan.

Søgaard, M. \& Jørgensen, A.N. (11. august 2017). 6-årige børn til lærere: “fuck dig!”. DR-nyheder, indland https://www.dr.dk/nyheder/indland/6-aarige-boern-til-laerere-fuck-dig 
Wissö, T. (2012). Småbarnsföräldrars vardagsliv: Omsorg, moral och social kapital. Göteborg Universitet, ph.d. afhandling.

Wouters, C. (2004). Changing regimes of manners and emotions: from disciplining to informalizing. In: S. Loyal \& S. Quilley (eds.), The Sociology of Norbert Elias. Cambridge, UK: Cambridge University Press.

Wouters, C. (2007). Informalization. Manners and Emotions since 1890. London: SAGE Publications.

Zelizer, V. (1985). Pricing the Priceless Child. The Changing Social Value of Children. Princeton: Princeton University Press.

Øland, T. (2010). A state ethnography of progressivism: Danish school pedagogues and their efforts to emancipate the powers of the child, the people and the culture 1929-1960. In: Praktiske grunde. Nordisk tidsskrift for kultur-og samfundsvidenskab, nr. 1-2. 